\title{
PENGARUH KECERDASAN INTELEKTUAL, KECERDASAN EMOSIONAL, KECERDASAN SPIRITUAL DAN GENDER TERHADAP SIKAP ETIS MAHASISWA PRODI PENDIDIKAN AKUNTANSI UIN SUSKA RIAU
}

\author{
Oleh : \\ Leny Nofianti \\ (Dosen Akuntansi Fakultas Ekonomi \& Ilmu Sosial UIN SUSKA RIAU)
}

\begin{abstract}
Abstrak
Tujuan yang hendak dicapai dalam penelitian ini adalah untuk mengetahui bagaimana pengaruh $\mathrm{IQ}, \mathrm{EQ}, \mathrm{SQ}$ dan gender terhadap sikap etis mahasiswa akuntansi, baik secara simultan maupun secara parsial dan untuk mengetahui manakah di antara variabel IQ, EQ, SQ dan gender yang berpengaruh dominan terhadap sikap etis mahasiswa akuntansi. Metode penelitian yang digunakan deskriptif verfikatif dengan analisis data dan pengujian hipotesis menggunakan analisi regresi berganda. Responden dalam penelitian ini adalah mahasiswa program studi pendidikan akuntansi UIN SUSKA Riau, yang telah mengambil mata kuliah Auditing. Hasil penelitian menunjukkan secara simultan pengaruh IQ,EQ,SQ dan Gender terhadap sikap etis menunjukkan pengaruh sebesar $0,529(52,9 \%)$ dan hasil uji menunjukkan pengaruh yan signifikan dimana $F_{\text {hit }}$ sebesar 9,837 lebih besar dari pada $\mathrm{F}_{\text {tabel }}$ untuk $\mathrm{db} 1=4$ dan $\mathrm{db} 2=35$ sebesar 2,641. Sementara pengaruh secara parsial terlihat bahwa pengaruh IQ terhadap sikap etis sebesar $12,7 \%$ dan dari hasil uji disimpulkan ada pengaruh yang signifikan dimana nilai $t_{\text {hit }}$ sebesar 2,256 lebih besar dari pada $t_{\text {tab }}$ sebesar 2,030 dan nilai signifikansi sebesar 0,030 lebih kecil dari 0,05, pengaruh EQ terhadap sikap etis sebesar $21,9 \%$ dan dari hasil uji disimpulkan ada pengaruh yang signifikan dimana nilai $t_{\text {hit }}$ sebesar 3,133 lebih besar dari pada $t_{\text {tab }}$ sebesar 2,030 dan nilai signifikansi sebesar 0,003 lebih kecil dari 0,05 , pengaruh SQ terhadap sikap etis sebesar $19,7 \%$ dan dari hasil uji disimpulkan ada pengaruh yang signifikan dimana nilai $t_{\text {hit }}$ sebesar 2,927 lebih besar dari pada $t_{\text {tab }}$ sebesar 2,030 dan nilai signifikansi sebesar 0,006 lebih kecil dari 0,05, sementara pengaruh Gender terhadap sikap etis sebesar $1,6 \%$ dan dari hasil uji disimpulkan pengaruh tidak signifikan dimana nilai $t_{\text {hit }}$ sebesar $-0,756$ lebih kecil dari pada $t_{\text {tab }}$ sebesar 2,030 dan nilai signifikansi sebesar 0,449 lebih besar dari 0,05 .
\end{abstract}

Kata Kunci : Kecerdasan Intelectual, Kecerdasan Emosional, Kecerdasan Spiritual, Gender, Sikap Etis

\section{Latar Belakang}

Dewasa ini profesi akuntan publik menjadi sorotan. Terutama setelah merebaknya kasus Enron yang melibatkan salah satu kantor akuntan publik The Big Five Arthur Andersen, serta berbagai kasus serupa yang terjadi di Indonesia meskipun dengan bentuk yang berbeda, penekanan pentingnya etika profesi khususnya bagi profesional di bidang akuntansi semakin menjadi perhatian. Perhatian terhadap pentingnya etika ini dilakukan mengingat kasus tersebut tak lepas dari akibat diabaikannya masalah etika profesi (Santoso, 2002) yang menimbulkan citra yang negatif terhadap profesi akuntan publik. Hal ini tentu saja akan merusak citra profesi akuntan di masyarakat yang pada akhirnya menurunkan kepercayaan masyarakat terhadap profesi akuntan. Pada setiap profesi sangat penting untuk menumbuhkan kepercayaan masyarakat terhadap kualitas jasa yang diberikan profesi tersebut. Selain itu pula profesi yang melayani kepentingan masyarakat hanya bisa mempertahankan eksistensinya jika masyarakat menghargai profesi yang bersangkutan dan penghargaan tersebut hanya akan diberikan oleh masyarakat jika ada usaha anggota profesi untuk bekerja dengan penuh tanggungjawab.

Akuntan memiliki profesi yang keberadaannya sangat tergantung pada kepercayaan masyarakat. Sebagai sebuah profesi yang kinerjanya diukur dari profesionalismenya, akuntan harus memiliki keterampilan, pengetahuan dan karakter. Penguasaan pengetahuan keterampilan 
tidaklah cukup bagi akuntan yang professional. Karakter diri yang dicirikan oleh ada dan tegaknya etika profesi merupakan hal yang penting.

Berbagai kasus pelanggaran etika seharusnya tidak terjadi apabila setiap akuntan mempunyai pengetahuan, pemahaman, dan kemauan untuk menerapkan nilai-nilai moral dan etika secara memadai dalam pelaksanaan pekerjaan profesionalnya (Ludigdo, 1999b). Oleh karena itu, terjadinya berbagai kasus sebagaimana disebutkan di atas, seharusnya memberi kesadaran untuk lebih memperhatikan etika dalam melaksanakan pekerjaan profesi akuntan.

Berbagai penelitian tentang etika, baik etika profesi akuntan maupun etika bisnis memberikan bukti empiris mengenai faktor-faktor yang mempengaruhi sikap dan perilaku etis seseorang (dalam hal ini akuntan, mahasiswa, manajer, karyawan, dan salesman) yang dapat dikelompokkan ${ }^{4} k$ dalam tiga aspek, yaitu: 1) Aspek individual; 2) Aspek organisasional; dan 3) Aspek lingkungan. Penelitian tentang etika yang berfokus pada aspek individual menunjukkan berbagai faktor yang mempengaruhi sikap dan perilaku etis seseorang antara lain: a) Religiusitas (Clark \& Dawson, 1996; Maryani \& Ludigdo, 2001; Weaver \& Agle 2002), b) Kecerdasan emosional (emotional quotient/EQ) (Maryani \& Ludigdo, 2001; Baihaqi, 2002), c) Gender (Ruegger \& King, 1992; Reiss \& Mitra, 1998; Abdulrahim, 1999; Chrismastuti \& Purnamasari, 2004), d) Suasana etis (ethical climate) individu (Wimbush, Shepard \& Markham, 1997), e) Sifatsifat personal (Verbeke, Ouwerkerk \& Peelen, 1996; Chrismastuti \& Purnamasari, 2004), dan f) Kepercayaan bahwa orang lain lebih tidak etis (Tyson, 1992).

Sementara, aspek organisasi yang mempengaruhi sikap dan perilaku etis seseorang meliputi faktor-faktor antara lain: a) Suasana etis organisasi (Verbeke dkk, 1996; Lovell, 2002), dan b) Suasana organisasi (Loeb, 1971; Adam, Tashchian \& Shore, 2001). Sedangkan aspek lingkungan yang mempengaruhi sikap dan perilaku etis seseorang meliputi: a) Lingkungan organisasi (Verbeke dkk, 1996), dan b) Lingkungan sosial (masyarakat) (Ludigdo, 2005).

Dalam perspektif yang lain Sudibyo (1995) dalam Khomsiyah \& Indriantoro (1998) mengemukakan bahwa dunia pendidikan akuntansi mempunyai pengaruh yang besar terhadap perilaku etika auditor. Ungkapan tersebut mengisyaratkan bahwa sikap dan perilaku etis auditor (akuntan) dapat terbentuk melalui proses pendidikan yang terjadi dalam lembaga pendidikan akuntansi, dimana mahasiswa sebagai input sedikit banyaknya akan memiliki keterkaitan dengan akuntan yang dihasilkan sebagai output.

Penelitian ini mengambil starting point penelitian yang telah dilakukan sebelumnya oleh M.Ridwan dkk (2006) yang meneliti tentang pengaruh IQ, EQ, dan SQ terhadap sikap etis mahasiswa akuntansi di Makasar. Perbedaan penelitian ini dengan penelitian sebelumnya adalah dengan menambahkan satu variabel atribut individu yaitu gender. Dengan alasan bahwa pada penelitian sebelumnya berkaitan dengan pengaruh gender terhadap etika menunjukkan hasil yang berbeda-beda dan belum konsisten, selain itu penelitian di Indonesia belum begitu banyak yang meneliti masalah ini.

Penelitian ini difokuskan pada aspek individual yang mempengaruhi sikap etis mahasiswa Jurusan maupun Program Studi Akuntansi (selanjutnya disebut mahasiswa akuntansi) di Kota Pekanbaru Provinsi Riau. Penelitian tentang sikap etis mahasiswa akuntansi juga telah pernah dilakukan oleh peneliti (Leny Nofianti, 2006) mengenai sensitivitas etis antara mahasiswa akuntansi dan mahasiswa non akuntansi, dengan temuan bahwa tidak ada perbedaan sensitivitas etis antara mahasiswa akuntansi dan mahasiswa non akuntansi pada Fakultas Ekonomi UIN Suska Riau. Dan pada penelitian ini peneliti tertarik untuk meneliti tentang faktor-faktor yang mempengaruhi sikap etis mahasiswa, sebagai kelanjutan dari penelitian sebelumnya.

Dengan demikian, penelitian yang berfokus pada aspek individual ini, ditekankan pada dimensi kecerdasan intelektual (IQ), kecerdasan emosional (EQ), kecerdasan spiritual (SQ) dan gender sebagai faktor yang mempengaruhi sikap etis mahasiswa akuntansi.

Penekanan penelitian ini pada dimensi IQ, EQ, SQ dan gender sebagai bagian dari aspek individual yang mempengaruhi sikap etis mahasiswa akuntansi didasarkan pada ungkapan bahwa IQ merupakan kemampuan untuk mengarahkan pikiran atau tindakan (Binet \& Simon dalam Azwar, 2004:5), bertindak dengan tujuan tertentu, berpikir rasional, menghadapi lingkungan dengan efektif (Wechsler dalam Azwar, 2004:7), serta dalam mengorganisasi pola-pola tingkah laku seseorang sehingga dapat bertindak lebih efektif dan lebih tepat (Freeman dalam Fudyartanta, 2004:12). EQ adalah kemampuan mengetahui perasaan sendiri dan perasaan orang lain, serta 
menggunakan perasaan tersebut menuntun pikiran dan perilaku seseorang (Salovey \& Mayer, 1990 dalam Svyantek, 2003). SQ adalah kecerdasan untuk menghadapi dan memecahkan persoalan makna dan nilai yang menempatkan perilaku dan hidup manusia dalam konteks yang lebih luas dan kaya (Zohar \& Marshall, 2002:4) yang memungkinkan seseorang untuk menyatukan hal-hal yang bersifat intrapersonal dan interpersonal, serta menjembatani kesenjangan antara diri sendiri dan orang lain (Zohar \& Marshall, 2002:12). Wujud dari SQ ini adalah sikap moral yang dipandang luhur oleh pelaku (Ummah dkk, 2003:43). Gender untuk melihat apakah terdapat perbedaan perilaku etis antara laki-laki dengan perempuan (Reiss \& Mitra, 1998).

\section{Rumusan Masalah}

${ }^{4}$ Berdasarkan latar belakang di atas, maka masalah dalam penelitian ini dapat dirumuskan:

a. Bagaimana pengaruh IQ, EQ, SQ dan gender terhadap sikap etis mahasiswa akuntansi, baik secara simultan maupun secara parsial

b. Manakah di antara variabel IQ, EQ, SQ dan gender yang berpengaruh dominan terhadap sikap etis mahasiswa akuntansi.

\section{Kerangka Pemikiran}

IQ merupakan interpretasi hasil tes inteligensi (kecerdasan) ke dalam angka yang dapat menjadi petunjuk mengenai kedudukan tingkat inteligensi seseorang (Azwar, 2004:51). Alfred Binet dan Theodore Simon mendefinisikan inteligensi sebagai suatu kemampuan yang terdiri dari tiga komponen, yaitu: a) Kemampuan untuk mengarahkan pikiran atau mengarahkan tindakan, b) Kemampuan untuk mengubah arah tindakan bila tindakan tersebut telah dilakukan, dan c) Kemampuan untuk mengeritik diri sendiri (Azwar, 2004:5). Sejalan dengan hal itu, David Wechsler mendefinisikan inteligensi sebagai totalitas kemampuan seseorang untuk bertindak dengan tujuan tertentu, berpikir secara rasional, serta menghadapi lingkungannya dengan efektif (Azwar, 2004:7). Raymond Bernard Cattell mengklasifikasikan kemampuan tersebut menjadi dua macam, yaitu: a) Inteligensi fluid, yang merupakan faktor bawaan biologis, dan b) Inteligensi crystallized, yang merefleksikan adanya pengaruh pengalaman, pendidikan, dan kebudayaan dalam diri seseorang (Azwar, 2004:3).

EQ adalah kemampuan mengetahui perasaan sendiri dan perasaan orang lain, serta menggunakan perasaan tersebut menuntun pikiran dan perilaku seseorang (Salovey \& Mayer, 1990 dalam Svyantek 2003). Sejalan dengan hal tersebut, Goleman (2005:512) mendefinisikan EQ adalah kemampuan mengenali perasaan diri sendiri dan perasaan orang lain, memotivasi diri sendiri, serta mengelola emosi dengan baik pada diri sendiri dan dalam hubungan dengan orang lain.

Goleman (2005:39) yang mengadaptasi model Salovey-Mayer membagi EQ ke dalam lima unsur yang meliputi: kesadaran diri, pengaturan diri, motivasi, empati, dan kecakapan dalam membina hubungan dengan orang lain. Kelima unsur tersebut dikelompokkan ke dalam dua kecakapan, yaitu: a) Kecakapan pribadi; yang meliputi kesadaran diri, pengaturan diri, dan motivasi; serta b) Kecakapan sosial; yang meliputi empati dan keterampilan sosial (Goleman, 2005:42-43).

SQ adalah kecerdasan untuk menghadapi dan memecahkan persoalan makna dan nilai, yaitu menempatkan perilaku dan hidup manusia dalam konteks makna yang lebih luas dan kaya, serta menilai bahwa tindakan atau jalan hidup seseorang lebih bermakna dibandingkan dengan yang lain (Zohar \& Marshall, 2002:4). SQ melampaui kekinian dan pengalaman manusia, serta merupakan bagian terdalam dan terpenting dari manusia (Pasiak, 2002:137).

Indikasi dari SQ yang telah berkembang dengan baik mencakup: a) Kemampuan untuk bersikap fleksibel, b) Adanya tingkat kesadaran diri yang tinggi, c) Kemampuan untuk menghadapi dan memanfaatkan penderitaan, d) Kemampuan untuk menghadapi dan melampaui perasaan sakit, e) Kualitas hidup yang diilhami oleh visi dan nilai-nilai, f) Keengganan untuk menyebabkan kerugian yang tidak perlu, g) Kecenderungan untuk berpandangan holistik, h) Kecenderungan untuk bertanya "mengapa" atau "bagaimana jika" dan berupaya untuk mencari jawaban-jawaban yang mendasar, i) Memiliki kemudahan untuk bekerja melawan konvensi (Zohar \& Marshall, 2002:14). 
SQ tidak mesti berhubungan dengan agama. SQ mendahului seluruh nilai spesifik dan budaya manapun, serta mendahului bentuk ekspresi agama manapun yang pernah ada. Namun bagi sebagian orang mungkin menemukan cara pengungkapan SQ melalui agama formal sehingga membuat agama menjadi perlu (Zohar \& Marshall, 2002:8-9).

SQ memungkinkan seseorang untuk menyatukan hal-hal yang bersifat intrapersonal dan interpersonal, serta menjembatani kesenjangan antara diri dan orang lain. (Zohar \& Marshall, 2002:12). Wujud dari kecerdasan spiritual ini adalah sikap moral yang dipandang luhur oleh pelaku (Ummah dkk, 2003:43). Matinya etika lama dan seluruh kerangka pikiran yang mendasarinya, memberi kesempatan yang berharga untuk menciptakan ajaran etika baru berdasarkan SQ (Zohar \& Marshall, 2002:175).

Konsep gender dalam penelitian ini berdasarkan konsep seks (jenis kelamin). Pengertian jenis kelamin merupakan kodrat yang ditentukan secara biologis (Rahmawati, 2003). Pria dan wanita akan menunjukkan perbedaan dalam perilaku dalam bertindak didasarkan pada sifat yang dimiliki dan kodrat yang telah diberikan secara biologis. Reiss dan Mitra melakukan penelitian tentang efek dari perbedaan faktor-faktor individual dalam kemampuan menerima perilaku etis atau tidak etis. Salah satu hasil penelitian menunjukkan bahwa wanita lebih etis dibandingkan pria.

Sikap dalam Kamus Lengkap Bahasa Indonesia (Dani, 2002:525) didefinisikan sebagai perbuatan dan sebagainya yang berdasarkan pendirian, pendapat atau keyakinan. Sementara definisi sikap menurut para ahli hingga saat ini masih berbeda pandangan, yang secara umum pandangan tersebut dibagi ke dalam tiga kelompok. Kelompok pertama yang diwakili oleh Thurstone, Likert, dan Osgood memandang sikap merupakan bentuk evaluasi atau reaksi perasaan terhadap suatu obyek, yang dapat berupa mendukung atau memihak maupun tidak mendukung atau tidak memihak. Kelompok kedua yang diwakili oleh Chave, Bogardus, LaPieree, Mead, dan Allport memandang sikap merupakan kesiapan untuk bereaksi terhadap suatu obyek dengan cara tertentu apabila individu dihadapkan pada suatu stimulus yang menghendaki adanya respon. Kelompok ketiga yang diwakili oleh Secord \& Backman memandang sikap merupakan konstelasi komponen-komponen kognitif, afektif, dan konatif yang saling berinteraksi dalam memahami, merasakan, dan berperilaku terhadap suatu obyek (Azwar, 2005:4-5). Berdasarkan ketiga pandangan di atas, sikap dapat didefinisikan sebagai reaksi individu terhadap suatu obyek yang merupakan konstelasi kognitif, afektif, dan konatif yang disebabkan oleh suatu stimulus yang menghendaki adanya respon (pendirian).

Sikap dan perilaku etis merupakan sikap dan perilaku yang sesuai dengan norma-norma sosial yang diterima secara umum sehubungan dengan tindakan-tindakan yang bermanfaat dan yang membahayakan (Griffin \& Ebert, 1998 dalam Maryani \& Ludigdo, 2001). Dengan demikian dalam kaitan dengan etika profesi, sikap dan perilaku etis merupakan sikap dan perilaku yang sesuai dengan etika profesi tersebut.

Etika merupakan filsafat atau pemikiran kritis dan mendasar tentang ajaran-ajaran dan pandangan-pandangan moral (Magnis-Suseno, 1997:14). Etika meliputi suatu proses penentuan yang kompleks tentang apa yang harus dilakukan seseorang dalam situasi tertentu yang disifati oleh kombinasi dari pengalaman dan pembelajaran masing-masing individu (Ward, Ward \& Deck, 1993). Etika sebagai ajaran moral pada umumnya tidak tertulis. Namun bagi suatu organisasi profesi (misalnya akuntan, dokter, pengacara), perilaku etis dituangkan dalam aturan tertulis yang disebut kode etik. Kode etik tersebut dibuat untuk dijadikan sebagai aturan tindakan etis bagi para anggota profesi yang bertujuan menjaga reputasi serta kepercayaan masyarakat agar profesi dapat tetap eksis dan survive.

Ikatan Akuntan Indonesia (IAI) sebagai organisasi profesi di bidang akuntansi di Indonesia memiliki Kode Etik yang mengikat para anggotanya. Kode Etik IAI sebagaimana ditetapkan dalam Kongres VIII IAI di Jakarta pada tahun 1998 terdiri dari tiga bagian, yaitu: a) Prinsip Etika, b) Aturan Etika, dan c) Interpretasi Aturan Etika. Kode Etik IAI tersebut menekankan pentingnya prinsip etika bagi para akuntan dalam melakukan kegiatan profesionalnya. Prinsip Etika dalam Kode Etik IAI terdiri dari delapan, yakni: (1) Tanggung jawab profesi, (2) Kepentingan publik, (3) Integritas, (4) Obyektivitas, (5) Kompetensi dan kehati-hatian profesional, (6) Kerahasiaan, (7) Perilaku profesional, dan (8) Standar teknis (Jusup, 2001:91) 


\section{Metodologi Penelitian}

Objek pada penelitian ini adalah mahasiswa Program Studi Pendidikan Akuntansi UIN Suska Riau, dengan kriteria responden telah menempuh Mata Kuliah Auditing I. Populasi dalam penelitian ini adalah seluruh mahasiswa Program Studi Pendidikan Akuntansi UIN Suska Riau, yang telah menempuh Mata Kuliah Auditing I. Pengambilan sampel dilakukan dengan teknik purposive sampling dengan pertimbangan (Judgment). Data yang digunakan dalam penelitian ini adalah data primer. Data diperoleh dengan membagikan angket atau kuesioner kepada responden.

Analisis data yang meliputi pengujian instrumen (uji validitas dan reliabitas), pengujian data (uji asumsi klasik), dan pengujian hipotesis dilakukan dengan program SPSS for Windows. Pengujian hipotesis penelitian ini dilakukan dengan analisis regresi berganda dengan model sebagai" berikut:

$$
\mathrm{EA}=\beta 0+\beta 1 \mathrm{IQ}+\beta 2 \mathrm{EQ}+\beta 3 \mathrm{SQ}+\mathrm{e}(\text { Gujarati, 2004:91) }
$$

\section{Definisi Operasional dan Pengukuran Variabel}

Untuk memberikan pemahaman yang lebih spesifik tehadap variabel penelitian ini maka variabel-variabel tersebut didefinisikan secara operasional sebagai berikut.

1. Sikap etis (ethical attitude/EA), adalah respon mahasiswa akuntansi terhadap kejadian yang mengandung situasi dilematis berdasarkan Prinsip Etika Kode Etik IAI . Variabel ini diperoleh dengan kuesioner yang terdiri dari tujuh item kejadian yang mengandung situasi dilematis dari perspektif Prinsip Etika Kode Etik IAI.

2. Kecerdasan intelektual (IQ), adalah tingkat intelegensi fluid dan inteligensi crystallized yang dimiliki mahasiswa akuntansi dengan penekanan pada kemampuan kognitif. Alat yang digunakan untuk mengetahui IQ mahasiswa adalah Standard Progressive Matrices " (Revised order 1956) Prepared by J.S.Raven M.Sc. Director of Psychological Research, the Crichton Royel, Dumfries.Dengan mengunakan grade: 19-20 sangat baik, 16-18 baik, 12-15 rata-rata atas, 9-11 rata-rata, 5-8 rata-rata bawah, 2-4 kurang dan 0-1 sangat kurang (versi Indonesia UI)

3. Kecerdasan emosional (EQ), adalah kemampuan mahasiswa akuntansi untuk mengenali perasaan diri sendiri dan perasaan orang lain, memotivasi diri sendiri, serta mengelola emosi dengan baik pada diri sendiri dan dalam hubungan dengan orang lain (Goleman, 2005:512).

4. Kecerdasan spiritual (SQ), adalah kemampuan mahasiswa akuntansi untuk menghadapi dan memecahkan persoalan makna dan nilai dengan menempatkan perilaku dan hidup manusia dalam konteks yang lebih luas dan kaya (Zohar \& Marshall, 2002:4).

5. Gender, adalah Konsep gender dalam penelitian ini berdasarkan konsep seks (jenis kelamin).Pengertian jenis kelamin merupakan kodrat yang ditentukan secara biologis (Rahmawati,2003). Pria dan wanita akan menunjukkan perbedaan dalam perilaku dalam bertindak didasarkan pada sifat yang dimiliki dan kodrat yang telah diberikan secara biologis. Dibagi menjadi dua yaitu pria dan wanita. Data ini diperoleh dari kuesioner bagian Data Demografi Responden.

\section{Hasil Penelitian Dan Pembahasan \\ Deskripsi Hasil Penelitian}

Dalam menggambarkan hasil penelitian pada bagian ini menggunakan analisis statistik deskriptif. Metode ini digunakan karena tujuan analisis pada bagian ini untuk mengetahui dari :

1. Gambaran mengenai Intelektual Quation (IQ)

2. Gambaran mengenai Emotional Quation (EQ)

3. Gambaran mengenai Spiritual Quation (SQ)

4. Gambaran mengenai Gender

5. Gambaran mengenai Sikap etis

Pada bagian ini menggunakan analisis sebaran jawaban responden pada masing-masing variabel dari jawaban kuesioner yang diedarkan pada responden.

1. Deskripsi Intelektual Quation (IQ)

Deskripsi untuk variabel X1 (Intelektual Quation) dilakukan dengan mengunakan psikolog. Alat yang digunakan untuk mengetahui IQ mahasiswa adalah Standard Progressive Matrices" (Revised order 1956) Prepared by J.S.Raven M.Sc. Director of Psychological Research, 
the Crichton Royel, Dumfries. Standar ini digunakan untuk pelajar Sekolah Menengah Atas (SMA) dan mahasiswa, dan standar ini dipilih dengan alasan bebas budaya.

2. Deskripsi Emotional Quation (EQ)

Gambaran mengenai Emotional Quation (EQ) berdasarkan pada sebaran jawaban responden atas pertanyaan yang disebarkan pada 40 responden terlihat pada tabel berikut :

Tabel 4.1

Tabulasi Sebaran Jawaban Responden Mengenai Emotional Quation (EQ)

\begin{tabular}{|c|c|c|c|c|c|c|}
\hline $\begin{array}{l}\text { No. Urut } \\
\text { Pertanyaan" }\end{array}$ & STS & TS & $\mathrm{TP}$ & $\mathrm{S}$ & SS & Jumlah \\
\hline 1 & 0 & 1 & 6 & 28 & 5 & 40 \\
\hline 2 & 0 & 0 & 1 & 15 & 24 & 40 \\
\hline 3 & 0 & 1 & 0 & 22 & 17 & 40 \\
\hline 4 & 0 & 0 & 6 & 24 & 10 & 40 \\
\hline 5 & 1 & 1 & 10 & 25 & 3 & 40 \\
\hline 6 & 0 & 0 & 4 & 31 & 5 & 40 \\
\hline 7 & 0 & 0 & 2 & 13 & 25 & 40 \\
\hline 8 & 0 & 1 & 6 & 28 & 5 & 40 \\
\hline
\end{tabular}

Berdasarkan tabel tersebut terlihat bahwa jawaban responden rata rata menjawab pada jawaban setuju. Adapun pernyataan ini meliputi :

$1 \quad$ Apabila ada masalah saya dapat menyelesaikannya dengan tenang

2 Saya bangga dengan hasil/kerjaan saya sendiri

3 Apabila ada teman sedang kesusahan saya berusaha untuk menghibur dan membantunya

$4 \quad$ Saya bisa menempatkan diri pada lingkungan baru

$5 \quad$ Saya mudah untuk beradaptasi pada lingkungan baru

6 Saya seorang yang disiplin dan bertanggung jawab

7 Dalam setiap pekerjaan/tindakan saya berusaha untuk mendapatkan nilai/hasil terbaik

8 Saya selalu memberikan pendapat/saran dalam setiap organisasi yang saya geluti

3. Deskripsi Spiritual Quation (SQ)

Untuk mencari gambaran mengenai Spiritual Quation (SQ) menggunakan pertanyaan sebagai berikut :

1 Saya selalu bersikap fleksibel dalam organisasi dan kehidupan sehari-hari

2 Saya yakin kekuasaan tertinggi hanya dimiliki oleh Allah SWT

$3 \quad$ Musibah yang datang saya anggap sebagai ujian dari Allah

$4 \quad$ Penderitaan saya anggap sebagai ladang ibadah

5 Apabila saya sakit, saya menghadapinya dengan ikhlas, karena datangnya dari Allah dan ada hikmah dibalik semuanya

6 Setiap ada masalah saya berusaha untuk mencari solusinya dan selalu mengembalikannya kepada Allah SWT

7 Dalam bertindak saya selalu memikirkan dampak positif dan negatifnya

8 Saya selalu bekerja/bertindak dengan semangat dan senang hati sebagai berikut :

Terhadap pertanyaan tersebut responden merespon dengan memberikan jawaban 
Tabel 4.2 Tabulasi Sebaran Jawaban Responden Mengenai Spiritual Quation (SQ)

\begin{tabular}{|c|c|c|c|c|c|c|}
\hline No.urut Pertanyaan & STS & TS & TT & S & SS & Jumlah \\
\hline 1 & 0 & 1 & 7 & 24 & 8 & 40 \\
\hline 2 & 0 & 0 & 0 & 3 & 37 & 40 \\
\hline 3 & 0 & 0 & 1 & 9 & 30 & 40 \\
\hline 4 & 0 & 3 & 1 & 21 & 15 & 40 \\
\hline 5 & 0 & 0 & 0 & 21 & 19 & 40 \\
\hline 6 & 0 & 0 & 0 & 15 & 25 & 40 \\
\hline 7 & 0 & 0 & 1 & 18 & 21 & 40 \\
\hline 8 & 0 & 0 & 1 & 25 & 14 & 40 \\
\hline
\end{tabular}

Pada item ini pun didominasi oleh jawaban setuju, dengan demikian rata rata responden setuju terhadap Spiritual Quation (SQ)yang harus dimiliki oleh setiap akuntan..

\section{Deskripsi Gender}

Gender yang dimaksudkan disini adalah jenis kelamin para responden. Statistik deskriptif dari jenis kelamin, yang dapat dilihat sebagai berikut:

Tabel 4.3

Jenis Kelamin

\begin{tabular}{|c|c|c|}
\hline Jenis Kelamin & Jumlah & Prosentase \\
\hline Pria & & \\
Wanita & 15 & 37,50 \\
Total & 25 & 62,50 \\
& 40 & 100,0 \\
\hline
\end{tabular}

Jenis kelamin yang paling banyak adalah perempuan yaitu sebesar 25 orang atau $62,50 \%$ dan jenis kelamin laki-laki sebanyak 15 orang atau 37,50\%.

\section{Deskripsi Sikap Etis}

Gambaran mengenai Emotional Quation (EQ) berdasarkan pada sebaran jawaban responden atas pertanyaan yang disebarkan pada 40 responden terlihat pada tabel berikut :

Tabel 4.4

Tabulasi Sebaran Jawaban Responden

Mengenai Emotional Quation (EQ)

\begin{tabular}{|c|r|r|r|r|r|r|}
\hline $\begin{array}{c}\text { No. Urut } \\
\text { Pertanyaan }\end{array}$ & STS & TS & TP & S & SS & \multicolumn{2}{|c|}{ Jumlah } \\
\hline 1 & 0 & 0 & 0 & 13 & 27 & 40 \\
\hline 2 & 0 & 1 & 2 & 24 & 13 & 40 \\
\hline 3 & 0 & 0 & 0 & 17 & 23 & 40 \\
\hline 4 & 0 & 0 & 1 & 15 & 24 & 40 \\
\hline 5 & 0 & 0 & 0 & 16 & 24 & 40 \\
\hline 6 & 0 & 2 & 0 & 11 & 27 & 40 \\
\hline 7 & 0 & 0 & 0 & 13 & 27 & 40 \\
\hline 8 & 0 & 2 & 2 & 27 & 9 & 40 \\
\hline
\end{tabular}

Berdasarkan tabel tersebut terlihat bahwa jawaban responden rata rata menjawab pada jawaban setuju. Adapun pernyataan ini meliputi : 
1 Setiap akuntan harus memiliki rasa tanggung jawab terhadap profesinya

2 Akuntan mendahulukan kepentingan publik

3 Akuntan menjaga integritas dalam melaksanakan tugasnya

$4 \quad$ Akuntan harus objektif dalam menjalankan tugasnya

$5 \quad$ Kompetensi dan kehati-hatian profesional harus dijaga oleh akuntan

$6 \quad$ Kerahasiaan dalam pekerjaan harus dijaga

7 Setiap akuntan berperilaku profesional

8 Dalam melaksanakan pekerjaan, akuntan mengunakan standar teknis

\section{Hasil Uji Validitas}

1. Hasil Validitas Variabel Sikap etis (Y)

Kuesioner penelitian Variabel Sikap etis (Y) terdiri atas 8 item. Hasil perhitungan korelasi untuk skor setiap butir pernyataan dengan total skor Variabel Sikap etis dapat dilihat dalam tabel berikut.

Tabel 4.5

Hasil Perhitungan Validitas Variabel Sikap etis ( (Y)

\begin{tabular}{|c|c|c|c|}
\hline $\begin{array}{c}\text { Item } \\
\text { Pernyataan }\end{array}$ & Korelasi & Nilai Batas & Kesimpulan \\
\hline Y.1 & 0.361 & 0,3 & Valid \\
Y.2 & 0.591 & 0,3 & Valid \\
Y.3 & 0.456 & 0,3 & Valid \\
Y.4 & 0.645 & 0,3 & Valid \\
Y.5 & 0.734 & 0,3 & Valid \\
Y.6 & 0.63 & 0,3 & Valid \\
Y.7 & 0.504 & 0,3 & Valid \\
Y.8 & 0.616 & 0,3 & Valid \\
\hline
\end{tabular}

Sumber : Hasil Pengolahan Data Penelitian

Hasil pengujian valitas item kuesioner menunjukkan bahwa seluruh item pernyataan dalam setiap Variabel Sikap etis (Y) memiliki nilai korelasi di atas 0,3 sebagai nilai batas suatu item kuesioner penelitian dikatakan dapat digunakan (dapat diterima). Sehingga dapat dikatakan bahwa item kuesioner variabel Sikap etis valid dan dapat digunakan untuk mengukur variabel yang diteliti.

\section{Hasil Validitas Variabel EQ (X2)}

Kuesioner penelitian Variabel EQ (X2) terdiri atas 8 item. Hasil perhitungan korelasi untuk skor setiap butir pernyataan dengan total skor Variabel EQ dapat dilihat dalam tabel berikut.

Tabel 4.6

Hasil Perhitungan Validitas Variabel EQ ( (X2)

\begin{tabular}{|c|c|c|c|}
\hline $\begin{array}{c}\text { Item } \\
\text { Pernyataan }\end{array}$ & Korelasi & Nilai Batas & Kesimpulan \\
\hline $\mathrm{X} 2.1$ & 0.574 & 0,3 & Valid \\
$\mathrm{X} 2.2$ & 0.445 & 0,3 & Valid \\
$\mathrm{X} 2.3$ & 0.753 & 0,3 & Valid \\
$\mathrm{X} 2.4$ & 0.68 & 0,3 & Valid \\
$\mathrm{X} 2.5$ & 0.781 & 0,3 & Valid \\
$\mathrm{X} 2.6$ & 0.387 & 0,3 & Valid \\
X2.7 & 0.546 & 0,3 & Valid \\
X2.8 & 0.443 & 0,3 & Valid \\
\hline
\end{tabular}

Sumber : Hasil Pengolahan Data Penelitian

Hasil pengujian valitas item kuesioner menunjukkan bahwa seluruh item pernyataan dalam setiap Variabel EQ (X2) memiliki nilai korelasi di atas 0,3 sebagai nilai batas suatu item kuesioner penelitian dikatakan dapat digunakan (dapat diterima). Sehingga dapat dikatakan bahwa item kuesioner Variabel EQ valid dan dapat digunakan untuk mengukur variabel yang diteliti. 
3. Hasil Validitas Variabel SQ (X3)

Kuesioner penelitian Variabel SQ (X3) terdiri atas 8 item. Hasil perhitungan korelasi untuk skor setiap butir pernyataan dengan total skor Variabel SQ dapat dilihat dalam tabel berikut.

Tabel 4.7

Hasil Perhitungan Validitas Variabel SQ ( (X3)

\begin{tabular}{|c|c|c|c|}
\hline $\begin{array}{c}\text { Item } \\
\text { Pernyataan }\end{array}$ & Korelasi & Nilai Batas & Kesimpulan \\
\hline X3.1 & 0.349 & 0,3 & Valid \\
X3.2 & 0.317 & 0,3 & Valid \\
X3.3 & 0.512 & 0,3 & Valid \\
X3.4 & 0.711 & 0,3 & Valid \\
X3.5 & 0.522 & 0,3 & Valid \\
X3.6 & 0.738 & 0,3 & Valid \\
X3.7 & 0.647 & 0,3 & Valid \\
X3.8 & 0.649 & 0,3 & Valid \\
\hline
\end{tabular}

Sumber : Hasil Pengolahan Data Penelitian

Hasil pengujian valitas item kuesioner menunjukkan bahwa seluruh item pernyataan dalam setiap Variabel SQ (X3) memiliki nilai korelasi di atas 0,3 sebagai nilai batas suatu item kuesioner penelitian dikatakan dapat digunakan (dapat diterima). Sehingga dapat dika

takan bahwa item kuesioner Variabel SQ valid dan dapat digunakan untuk mengukur variabel yang diteliti.

\section{Hasil Uji Reliabilitas}

Uji Reliabilitas digunakan untuk mengukur tingkat kekonsistenan tanggapan responden terhadap item pernyataan kuesioner berdasarkan pemahaman responden terhadap pertanyaanpertanyaan dalam kuesioner yang diajukan. Uji Reliabilitas dilakukan dengan metode Alpha. Hasil perhitungan koefisien reliabilitas untuk masing-masing variabel diberikan pada tabel berikut.

Tabel 4.8

Hasil Pengujian Reliabilitas

\begin{tabular}{|c|l|c|c|}
\hline No & \multicolumn{1}{|c|}{ Variabel } & $\begin{array}{c}\text { Koefisien } \\
\text { Reliabilitas }\end{array}$ & Keterangan \\
\hline 1 & Sikap etis (Y) & 0,698 & Reliabel \\
\hline 2 & EQ ( (X2) & 0,727 & Reliabel \\
\hline 3 & SQ ( (X3) & 0,672 & Reliabel \\
\hline
\end{tabular}

Sumber : Hasil Pengolahan Data Penelitian

Hasil koefisien reliabilitas untuk variabel Sikap etis (Y), EQ (X2) dan SQ (X3) diperoleh diatas 0,6 sebagai nilai batas suatu instrumen penelitian dikatakan dapat digunakan (Reliabel).

\section{Pengujian Asumsi Regresi Uji Asumsi Klasik}

Persamaan regresi linier yang diperoleh melalui metode penaksiran OLS (Ordinary Least Squares) dapat dikatakan baik untuk menggambarkan hubungan fungsional sekelompok variable bebas terhadap variable tak bebas jika persamaan tersebut memenuhi asumsi-asumsi regresi klasik. Asumsi regresi yang dilihat adalah asumsi error mengikuti distribusi normal, asumsi bebas kolinearitas dan asumsi tidak terdapat heteroskedastis.

Uji Normalitas

Pengujian normalitas residu dilakukan untuk memenuhi asumsi regresi yang mensyaratkan residual nilai taksiran model regresi harus berdistribusi normal. Pada penelitian ini uji normalitas menggunakan Uji Kolmogorov- Smirnov. Hasil perhitungan uji normalitas residual dari persamaan taksiran yang diperoleh menggunakan SPSS adalah sebagai berikut : 
Tabel 4.9

Hasil Uji Normalitas

One-Sample Kolmogorov-Smirnov Test

\begin{tabular}{|c|c|c|}
\hline & & $\begin{array}{c}\text { Unstandardized } \\
\text { Residual }\end{array}$ \\
\hline $\mathrm{N}$ & & 40 \\
\hline \multirow[t]{2}{*}{ Normal Parameters ${ }^{\mathrm{a}, \mathrm{b}}$} & Mean & .0000000 \\
\hline & Std. Deviation & 1.81519605 \\
\hline \multirow[t]{3}{*}{ Most Extreme Differences } & Absolute & .083 \\
\hline & Positive & .068 \\
\hline & Negative & -.083 \\
\hline Kolmogorov-Smirnov Z & & .524 \\
\hline Asymp. Sig. (2-tailed) & & .946 \\
\hline
\end{tabular}

a. Test distribution is Normal.

b. Calculated from data.

Dari tabel diatas dapat dilihat bahwa nilai $\mathrm{D}_{\text {hitung }}=0,083$ dengan $\mathrm{p}$-value (nilai sig) sebesar 0,946. Diperoleh dari hasil penghitungan uji Normalitas untuk data nilai residual dari model signifikansi (p) adalah 0,946 berada di atas 0,05 . Hasil pengujian normalitas model regresi menunjukkan bahwa nilai residual dari model berdistribusi normal.

Pengujian normalitas data juga dilakukan dengan melihat penyebaran data (titik) pada sumbu diagonal dari grafik. Dasar pengambilan keputusan adalah jika data menyebar di sekitar garis diagonal dan mengikuti arah garis diagonal, maka model regresi memenuhi asumsi normalitas. Dari grafik output SPSS di bawah ini terlihat bahwa titik-titik menyebar di sekitar garis diagonal, serta penyebarannyamengikuti arah garis diagonal. Maka model regresi layak dipakai untuk prediksi sikap etis berdasar masukan variabel independentnya.

Gambar 4.1

Grafik Uji normalitas

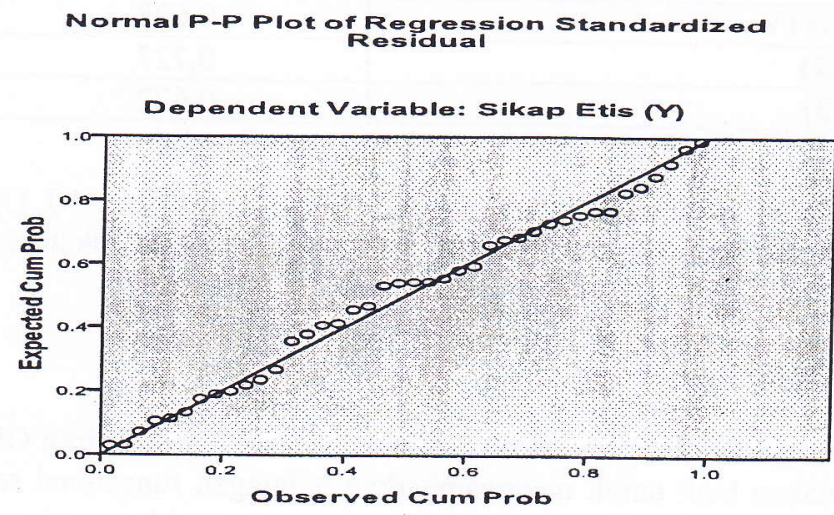

a. Uji Multikolinearitas

Tabel 4.10

Rekapitulasi hasil uji Multikolonieritas

\begin{tabular}{|c|r|r|c|}
\hline Variabel & Tolerance & \multicolumn{1}{|c|}{ VIF } & Keterangan \\
\hline IQ & 0.739 & 1.353 & Bebas Multikolinearitas \\
\hline EQ & 0.986 & 1.014 & Bebas Multikolinearitas \\
\hline SQ & 0.764 & 1.309 & Bebas Multikolinearitas \\
\hline Gender & 0.955 & 1.047 & Bebas Multikolinearitas \\
\hline
\end{tabular}


Dari tabel di atas, dapat diketahui bahwa nilai Variance Inflation Factor (VIF) keempat variabel lebih kecil dari 5, maka bisa disimpulkan bahwa antar variabel tidak terjadi persoalan multikolinearitas dan layak digunakan.

b. Uji Asumsi Bebas Heterokedastisitas

Heteroskedastisitas merupakan indikasi bahwa varians residual tidak homogen yang mengakibatkan nilai taksiran yang diperoleh tidak lagi efisien. Pengujian homogenitas varian dari residual model regresi dalam penelitian ini menggunakan pendekatan uji Korelasi Rank Spearman. Tabel 4.11

Uji Heteroskedastisitas

भ Correlations $^{\mathrm{a}}$

\begin{tabular}{|lll|r|}
\hline & & \multicolumn{1}{c|}{ absr } \\
\hline Spearman's rho & IQ (X1) & Correlation Coefficient & -.239 \\
& & Sig. (2-tailed) & .138 \\
\cline { 2 - 4 } & EQ (X2) & Correlation Coefficient & -.025 \\
& Sig. (2-tailed) & .876 \\
\cline { 2 - 4 } & SQ (X3) & Correlation Coefficient & -.044 \\
& Sig. (2-tailed) & .786 \\
\cline { 2 - 4 } & Gender (X4) & Correlation Coefficient & -.034 \\
& Sig. (2-tailed) & .837 \\
\hline
\end{tabular}

a. Listwise $\mathrm{N}=40$

Hasil pengujian heteroskedastisitas menunjukkan bahwa varians dari residual homogen (tidak terdapat heteroskedastisitas). Hal ini ditunjukan oleh hasil korelasi X dengan nilai absolut dari residual (error) tidak signifikan pada level 5\%. Diperoleh nilai signifikansi untuk X1 sebesar 0,138 , untuk X2 sebesar 0,876 , untuk X3 sebesar 0,786 , dan untuk X4 sebesar 0,873 , (nilai signifikansi lebih besar dari 0,05 sebagai batas tingkat kekeliruan).

Cara lain untuk mendeteksi ada atau tidaknya heterokedastisitas adalah dengan melihat grafik plot antara nilai prediksi variabel terikat (ZPRED) dengan nilai residualnya (SDRESID). Jika tidak ada pola yang jelas dan titik-titik menyebar di atas dan di bawah angka 0 pada sumbu $Y$, maka tidak terjadi heterokedastisitas. Hasil pengujian heterokedastisitas pada penelitian ini dapat dilihat pada gambar berikut ini :

Gambar 4.2

Grafik Uji Heterokedastisitas

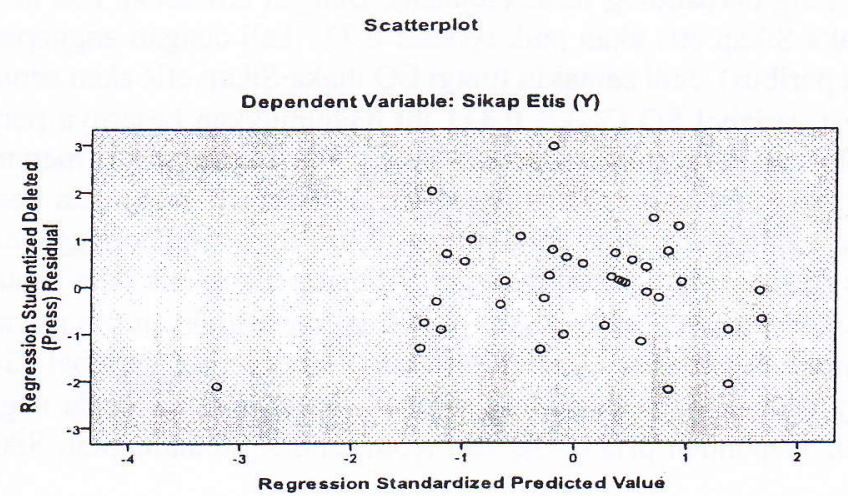


Dari grafik tersebut, dapat diketahui bahwa model regresi dalam penelitian ini tidak terdapat gangguan heterokedastisitas karena tidak ada pola yang jelas pada titik-titiknya. Titiktitiknya juga menyebar di atas dan di bawah angka 0 pada sumbu $\mathrm{Y}$, kondisi ini menunjukkan tidak terjadinya heterokedastisitas.

\section{Hasil Pengujian Hipotesis dan Pembahasan}

Hasil perhitungan dengan menggunakan alat bantu SPSS V 17 diperoleh hasil penghitungan diperoleh koefisien regresi dan nilai konstanta seperti pada tabel berikut :

Tabel 4.12

,

Hasil Koefisien regresi

\begin{tabular}{|c|c|c|c|c|c|c|}
\hline \multicolumn{7}{|c|}{ Coefficients $^{a}$} \\
\hline \multirow{2}{*}{\multicolumn{2}{|c|}{ Model }} & \multicolumn{2}{|c|}{$\begin{array}{c}\text { Unstandardized } \\
\text { Coefficients }\end{array}$} & \multirow{2}{*}{$\frac{\begin{array}{c}\text { Standardized } \\
\text { Coefficients }\end{array}}{\text { Beta }}$} & \multirow[b]{2}{*}{$\mathrm{t}$} & \multirow[b]{2}{*}{ Sig. } \\
\hline & & B & Std. Error & & & \\
\hline \multirow[t]{5}{*}{1} & (Constant) & 5.879 & 5.398 & & 1.089 & .284 \\
\hline & IQ (X1) & .294 & .130 & .304 & 2.256 & .030 \\
\hline & $\mathrm{EQ}(\mathrm{X} 2)$ & .337 & .107 & .366 & 3.133 & .003 \\
\hline & $\mathrm{SQ}(\mathrm{X} 3)$ & .411 & .140 & .388 & 2.927 & .006 \\
\hline & Gender (X4) & -.490 & .640 & -.091 & -.765 & .449 \\
\hline
\end{tabular}

a. Dependent Variable: Sikap Etis (Y) etis adalah:

Persamaan regresi yang menjelasakan pengaruh IQ,EQ,SQ dan Gender terhadap sikap

$Y=5,879+0,294 X_{1}+0,337 X_{2}+0,411 X_{3}-0,490 X_{2}$ Dari persamaan regresi yang diperoleh dapat dijelaskan :

- Konstanta sebesar 5,879 menyatakan bahwa Sikap Etis (Y) sebesar 5,879 satuan kalau variabel etika kerja Islam dan variabel etika bisnis dianggap konstan (cateris paribus).

- Koefisien regresi variabel IQ $\left(\mathrm{X}_{1}\right)=0,294$ ini menunjukkan besarnya perubahan Sikap etis karena pengaruh variabel tersebut terhadap Sikap etis. Tanda positif menunjukkan koefesien arah hubungan yang berbanding lurus (sejalan). Dengan arti setiap ada kenaikan satu satuan variabel IQ maka Sikap etis akan meningkat sebesar 0,294 kali dengan anggapan faktor yang lain konstan (cateris paribus). Jadi semakin tinggi IQ maka Sikap etis akan semakin tinggi (baik).

- Koefisien regresi variabel EQ $\left(\mathrm{X}_{2}\right)=0,337$ ini menunjukkan besarnya perubahan Sikap etis karena pengaruh variabel tersebut terhadap Sikap etis. Tanda positif menunjukkan koefesien arah hubungan yang berbanding lurus (sejalan). Dengan arti setiap ada kenaikan satu satuan variabel EQ maka Sikap etis akan naik sebesar 0,337 kali dengan anggapan faktor yang lain konstan (cateris paribus). Jadi semakin tinggi EQ maka Sikap etis akan semakin tinggi (baik).

- Koefisien regresi variabel SQ $\left(\mathrm{X}_{3}\right)=0,411$ ini menunjukkan besarnya perubahan Sikap etis karena pengaruh variabel tersebut terhadap Sikap etis. Tanda positif menunjukkan koefesien arah hubungan yang berbanding lurus (sejalan). Dengan arti setiap ada kenaikan satu satuan variabel SQ maka Sikap etis akan naik sebesar 0,411 kali dengan anggapan faktor yang lain konstan (cateris paribus). Jadi semakin tinggi SQ maka Sikap etis akan semakin tinggi (baik).

- Koefisien regresi variabel Gender $\left(X_{4}\right)=-0,490$ ini menunjukkan besarnya perubahan Sikap etis karena pengaruh variabel Gender terhadap Sikap etis. Variabel Gender merupakan variabel dummy dengan skor 1 untuk pria dan 0 untuk wanita. Tanda negatif menunjukkan bahwa Sikap etis responden pria 0,490 kali lebih rendah dibandingkan Sikap etis responden wanita. 


\section{Besar Pengaruh}

Tabel 4.13 Hasil regresi

Model Summary ${ }^{\mathrm{b}}$

\begin{tabular}{|l|r|r|r|r|}
\hline Model & \multicolumn{1}{|c|}{$\mathrm{R}$} & R Square & \multicolumn{1}{c|}{$\begin{array}{c}\text { Adjusted R } \\
\text { Square }\end{array}$} & $\begin{array}{c}\text { Std. Error of the } \\
\text { Estimate }\end{array}$ \\
\hline 1 & $.727^{\mathrm{a}}$ & .529 & .475 & 1.91612 \\
\hline
\end{tabular}

a. Predictors: (Constant), Gender (X4), EQ (X2), SQ (X3), IQ (X1)

b. Dependent Variable: Sikap Etis (Y)

Besarnya pengaruh IQ,EQ,SQ dan Gender terhadap sikap etis dapat dilihat nilai korelasi dan koefisien determinasi $\left(\mathrm{R}^{2}\right)$. Tabel di atas merupakan hasil perhitungan koefisien determinasi untuk persamaan regresi yang diperoleh. Hasil yang diperoleh menunjukkan bahwa secara simultan pengaruh IQ,EQ,SQ dan Gender terhadap sikap etis menunjukkan pengaruh sebesar $0,529(52,9 \%)$. Pengaruh yang diperleh cukup besar. Sedangkan $100 \%-52,9 \%=47,1 \%$ lainnya dipengaruhi faktor lain yang tidak termasuk dalam variabel yang diteliti dalam penelitian ini. Jika dilihat dari tingkat hubungan IQ,EQ,SQ dan Gender dengan sikap etis masuk dalam kategori kuat (erat) dengan besar korelasi 0,727.

Untuk mengetahui pengaruh masing-masing variabel secara parsial dapat dilihat dari penghitungan korelasi parsial yaitu koefisien hubungan dengan mengontrol variabel bebas baik secara sendiri-sendiri maupun secara bersama-sama. Adapun hasil penghitungan korelasi parsial dapat dilihat pada tabel berikut:

Tebel 4.14 Hasil Penghitungan Korelasi Parsial $\mathrm{r}_{\mathrm{yx1.x2}}$

\begin{tabular}{|c|l|r|r|}
\hline Korelasi Parsial & \multicolumn{1}{|c|}{$\mathrm{N}$} & \multicolumn{1}{|c|}{$\mathrm{R}$} & \multicolumn{1}{c|}{$\mathrm{r}^{2}$} \\
\hline $\mathbf{r}_{\mathbf{y} \times 1 . \times 2 . \times 3 . \times 4}$ & 40 & 0.356 & $12.7 \%$ \\
\hline $\mathrm{r}_{\mathrm{y} \times 2 . \times 1 \times 3 . \times 4}$ & 40 & 0.468 & $21.9 \%$ \\
\hline $\mathrm{r}_{\mathrm{y} \times 3 . \times 1 . \times 2 . \times 4}$ & 40 & 0.443 & $19.7 \%$ \\
\hline $\mathrm{r}_{\mathbf{y} \times 4 \times 1 . \times 2 . \times 3}$ & 40 & -0.128 & $1.6 \%$ \\
\hline
\end{tabular}

Apabila dilakukan pengontrolan terhadap variabel EQ,SQ dan Gender, diperoleh korelasi parsial IQ dengan sikap etis $\left(\mathbf{r}_{\mathbf{y x} 1 . \times 2 . \times 3 . \times 4}\right)$ sebesar 0,356 . Hubungan yang terjadi masuk dalam kategori tidak kuat (tidak erat). Berdasarkan koefisien korelasi tersebut di atas diperoleh koefisien determinasi $\left(r^{2}\right)$ sebesar $12.7 \%$. Hal ini berarti bahwa pengaruh IQ terhadap sikap etis apabila dilakukan pengontrolan terhadap variabel EQ,SQ dan Gender ada sebesar 12,7\%.

Apabila dilakukan pengontrolan terhadap variabel IQ,SQ dan Gender, diperoleh korelasi parsial EQ dengan sikap etis $\left(\mathbf{r}_{\mathbf{y x} 2 \times 1 . \times 3 . \times 4}\right)$ sebesar 0,468 . Hubungan yang terjadi masuk dalam kategori cukup kuat (cukup erat). Berdasarkan koefisien korelasi tersebut di atas diperoleh koefisien determinasi $\left(\mathrm{r}^{2}\right)$ sebesar $21,9 \%$. Hal ini berarti bahwa pengaruh EQ terhadap sikap etis apabila dilakukan pengontrolan terhadap variabel IQ,SQ dan Gender ada sebesar 21,9\%.

Apabila dilakukan pengontrolan terhadap variabel IQ, EQ dan Gender, diperoleh korelasi parsial SQ dengan sikap etis $\left(\mathbf{r}_{y \times 3 \times 1 \times 1 \times 1 \times \times 4}\right)$ sebesar 0,443. Hubungan yang terjadi masuk dalam kategori cukup kuat (cukup erat). Berdasarkan koefisien korelasi tersebut di atas diperoleh koefisien determinasi $\left(\mathrm{r}^{2}\right)$ sebesar $19,7 \%$. Hal ini berarti bahwa pengaruh SQ terhadap sikap etis apabila dilakukan pengontrolan terhadap variabel IQ,EQ dan Gender ada sebesar 19,7\%.

Apabila dilakukan pengontrolan terhadap variabel IQ,EQ dan SQ, diperoleh korelasi parsial Gender dengan sikap etis $\left(\mathbf{r}_{\mathbf{y x} 4 . \times 1 . \times 1 . \times 3}\right)$ sebesar 0,128 . Hubungan yang terjadi masuk dalam kategori sangat kecil. Berdasarkan koefisien korelasi tersebut di atas diperoleh koefisien determinasi $\left(\mathrm{r}^{2}\right)$ sebesar $1,6 \%$. Hal ini berarti bahwa pengaruh perbedaan gender terhadap sikap etis pada saat IQ,EQ dan SQ dikontrol (tidak berbeda) sangatkecil hanya ada sebesar 1,6\%. 


\section{Pengujian hipotesis Secara Simultan}

Pengujian signifikansi persamaan regresi yang diperoleh digunakan uji varians (anava)uji $F$. Kriteria signifkansi, jika $F_{\text {hit }}$ lebih besar dari pada $F_{\text {tab }}$ maka persamaan regresi ganda tersebut dinyatakan signifikan. Yang berarti secara bersama-sama IQ,EQ,SQ dan Gender berpengaruh terhadap sikap etis. Penghitungan uji signifikansi dapat dilihat pada tabel dibawah ini :

Tabel 4.15

Tabel ANAVA untuk Uji Signifkansi

\begin{tabular}{|ll|r|r|r|r|r|}
\hline \multicolumn{1}{|c|}{ Model $^{1}$} & Sum of Squares & \multicolumn{1}{c|}{ df } & Mean Square & F & \multicolumn{1}{c|}{ Sig. } \\
\hline 1 & Regression & 144.472 & 4 & 36.118 & 9.837 & $.000^{\mathrm{a}}$ \\
& Residual & 128.503 & 35 & 3.672 & & \\
& Total & 272.975 & 39 & & & \\
\hline
\end{tabular}

a. Predictors: (Constant), Gender (X4), EQ (X2), SQ (X3), IQ (X1)

b. Dependent Variable: Sikap Etis (Y)

Pada tabel di atas dapat diketahui $\mathrm{F}_{\text {hit }}$ sebesar 9,837 lebih besar dari pada $\mathrm{F}_{\text {tabel }}$ untuk db1 $=4$ dan $\mathrm{db} 2=35$ sebesar 2,641 dan juga jika dilihat dari nilai signifikansi sebesar 0,000 (sangat kecil) lebih kecil dari 0,05 . Sehingga persamaan regresi ganda dapat dinyatakan signifikan yang berarti bahwa apabila secara bersama-sama IQ,EQ,SQ dan Gender berpengaruh terhadap sikap etis.

\section{Pengujian hipotesis Secara Parsial}

Sementara pengaruh secara parsial terlihat dari uji t. Untuk pengaruh IQ terhadap sikap etis diperoleh nilai $t$ hitung sebesar 2,256 dengan signifikansi 0,030 . Nilai $t_{\text {hit }}$ sebesar 2,256 lebih besar dari pada $t_{\text {tab }}$ sebesar 2,030. Maka dapat disimpulkan bahwa $\mathrm{HO}$ ditolak yang berarti diterdapat pengaruh yang signifikan IQ terhadap sikap etis. Dan juga jika dilihat dari nilai signifikansi sebesar 0,030 lebih kecil dari 0,05.

Untuk pengaruh EQ terhadap sikap etis diperoleh nilai t hitung sebesar 3,133 dengan signifikansi 0,003 . Nilai $t_{\text {hit }}$ sebesar 3,133 lebih besar dari pada $t_{\text {tab }}$ sebesar 2,030. Maka dapat disimpulkan bahwa H0 ditolak yang berarti diterdapat pengaruh yang signifikan EQ terhadap sikap etis. Dan juga jika dilihat dari nilai signifikansi sebesar 0,003 lebih kecil dari 0,05.

Untuk pengaruh SQ terhadap sikap etis diperoleh nilai $t$ hitung sebesar 2,927 dengan signifikansi 0,006 . Nilai $t_{\text {hit }}$ sebesar 2,927 lebih besar dari pada $t_{\text {tab }}$ sebesar 2,030. Maka dapat disimpulkan bahwa H0 ditolak yang berarti diterdapat pengaruh yang signifikan SQ terhadap sikap etis. Dan juga jika dilihat dari nilai signifikansi sebesar 0,006 lebih kecil dari 0,05.

Untuk pengaruh Gender terhadap sikap etis diperoleh nilai t hitung sebesar $-0,756$ dengan signifikansi 0,449 . Nilai $t_{\text {hit }}$ sebesar $-0,756$ lebih kecil dari pada $t_{\text {tab }}$ sebesar 2,030. Maka dapat disimpulkan bahwa $\mathrm{H} 0$ tidak ditolak yang berarti tidak terdapat pengaruh yang signifikan SQ terhadap sikap etis. Dan juga jika dilihat dari nilai signifikansi sebesar 0,003 lebih kecil dari 0,05.

\section{Simpulan}

1. Dari hasil penelitian dapat disimpulkan bahwa secara simultan pengaruh IQ,EQ,SQ dan Gender terhadap sikap etis menunjukkan pengaruh sebesar 0,529 (52,9\%) dan hasil uji menunjukkan pengaruh yan signifikan dimana $F_{\text {hit }}$ sebesar 9,837 lebih besar dari pada $F_{\text {tabel }}$ untuk $\mathrm{db} 1=4$ dan $\mathrm{db} 2=35$ sebesar 2,641. Sementara pengaruh secara parsial terlihat bahwa pengaruh IQ terhadap sikap etis sebesar $12,7 \%$ dan dari hasil uji disimpulkan ada pengaruh yang signifikan dimana nilai $t_{\text {hit }}$ sebesar 2,256 lebih besar dari pada $t_{\text {tab }}$ sebesar 2,030 dan nilai signifikansi sebesar 0,030 lebih kecil dari 0,05, pengaruh EQ terhadap sikap etis sebesar $21,9 \%$ dan dari hasil uji disimpulkan ada pengaruh yang signifikan dimana nilai $t_{\text {hit }}$ sebesar 3,133 lebih besar dari pada $t_{\text {tab }}$ sebesar 2,030 dan nilai signifikansi sebesar 0,003 lebih kecil dari 0,05, pengaruh SQ terhadap sikap etis sebesar $19,7 \%$ dan dari hasil uji 
disimpulkan ada pengaruh yang signifikan dimana nilai $t_{\text {hit }}$ sebesar 2,927 lebih besar dari pada $t_{\text {tab }}$ sebesar 2,030 dan nilai signifikansi sebesar 0,006 lebih kecil dari 0,05 , sementara pengaruh Gender terhadap sikap etis sebesar 1,6\% dan dari hasil uji disimpulkan pengaruh tidak signifikan dimana nilai $t_{\text {hit }}$ sebesar $-0,756$ lebih kecil dari pada $t_{\text {tab }}$ sebesar 2,030 dan nilai signifikansi sebesar 0,449 lebih besar dari 0,05 ,

2. Secara keseluruhan penelitian ini menunjukkan bahwa hasil penelitian ini yang menunjukkan IQ, EQ, SQ dan Gender secara simultan berpengaruh signifikan terhadap sikap etis mahasiswa akuntansi sedangkan secara parsial hanya gender yang tidak berpengaruh signifikan, menggambarkan beberapa hal yang patut dicermati, yakni: 1) IQ, EQ, dan SQ merupakan 'trio kecerdasan' yang tak terpisahkan dalam kehidupan seseorang. Oleh karena itu', dalam upaya pembentukan dan pengembangan sikap (dan perilaku) etis mahasiswa akuntansi maupun akuntan, perlu mengembangkan 'trio kecerdasan' tersebut secara komprehensif dan proporsional, dan IQ bukanlah satu-satunya dasar dalam bersikap, tapi ada factor lain yang sangat menentukan yaitu EQ dan SQ.2) Pengembangan IQ, EQ, dan SQ yang dilakukan secara tidak komprehensif dan tidak proporsional akan memberi peran yang dominan terhadap IQ seseorang dalam bersikap dan berperilaku etis. Hal ini akan memberi peluang terjadinya sikap dan perilaku mahasiswa akuntansi maupun akuntan yang hanya mempertimbangkan rasionalitas dalam melakukan tugas dan kewajiban profesionalnya. Pertimbangan yang hanya didasarkan pada rasionalitas cenderung menekankan pada hal-hal yang bersifat menguntungkan (finansial) dan mengabaikan hal-hal yang bersifat etis. Dalam keadaan demikian kemungkinan terjadinya perilaku yang menyimpang akan semakin besar

\section{Saran}

1. Bagi lembaga pendidikan akuntansi dan IAI, perlu melakukan upaya untuk mengembangkan IQ, EQ, dan SQ anak didik dan anggotanya secara komprehensif dan proporsional dalam pembentukan manusia (akuntan) yang memiliki sikap dan perilaku etis yang tinggi

2. Bagi peneliti selanjutnya, dapat mengembangkan penelitian ini pada dimensi-dimensi lain dari aspek individual, pada aspek organisasi dan lingkungan, pada responden mahasiswa akuntansi dan akuntan, serta dengan pertautan antarvariabel yang bersifat interaksi atau dengan menambahkan variabel tertentu sebagai variabel moderating maupun sebagai variabel intervening.

Daftar Pustaka

Abdulrahim, A. 1999. Pengaruh Perbedaan Gender terhadap Perilaku Akuntan Pendidik. Tesis. Program Pascasarjana Universitas Gadjah Mada, Yogyakarta.

Adam, J.S; A. Tashchian \& T.H. Shore. 2001. Code of Ethics as Signals for Ethical Behavior. Journal of Business Ethics 29: 199-211.

Agustian, A.G. 2004a. Rahasia Sukses Membangun Kecerdasan Emosi dan Spiritual (ESQ) Berdasarkan 6 Rukun Iman dan 5 Rukun Islam. Cetakan Kedelapanbelas. Arga, Jakarta.

Agustian, A.G. 2004b. Rahasia Sukses Membangkitan ESQ Power: Sebuah Inner Journey Melalui Al-Ihsan. Cetakan Ketiga. Arga, Jakarta.

Aliman. 2000. Modul Ekonometrika Terapan. PAU Studi Ekonomi UGM, Yogyakarta.

Arief, S. 1993. Metodologi Penelitian Ekonomi. UI Press, Jakarta.

Arikunto, S. 1998. Prosedur Penelitian. Rineka Cipta, Jakarta.

Azwar, S. 2004. Pengantar Psikologi Inteligensi. Cetakan Keempat. Pustaka Pelajar, Yogyakarta.

Azwar, S. 2005. Sikap Manusia: Teori dan Pengukurannya. Edisi Kedelapan. Pustaka Pelajar, Yogyakarta.

Baihaqi, S. 2002. Analisis Pengaruh EQ Karyawan terhadap Kualitas Perilaku Pelayanan Kepada Wajib Pajak di Kantor Pelayanan PBB (Studi pada KPPBB Kediri dan Tulung Agung). Skripsi. Fakultas Ekonomi Universitas Gadjah Mada, Yogyakarta.

Bulo, W.E.L. 2002. Pengaruh Pendidikan Tinggi Akuntansi terhadap EQ. Skripsi. Fakultas Ekonomi Universitas Gadjah Mada, Yogyakarta. 
Chrismastuti, A.A. \& V. Purnamasari. 2004. Hubungan Sifat Machiavellian, Pembelajaran Etika dalam Mata Kuliah Etika, dan Sikap Etis Akuntan: Suatu Analisis Perilaku Etis Akuntan dan Mahasiswa Akuntansi di Semarang. Proceeding Simposium Nasional Akuntansi VII. Denpasar, 2-3 Desember: 247-266.

Clark, J.W. \& L.E. Dawson. 1996. Personal Religiousness and Ethical Judgement: An Empirical Analysis. Journal of Business Ethics 15: 359-372.

Dajan, A. 1986. Pengantar Metode Statistik. Jilid 1 \& 2. LP3ES, Jakarta.

Dani, K. 2002. Kamus Lengkap Bahasa Indonesia. Putra Harsa, Surabaya.

Darwis. 2004. Pengaruh Ideologi Etik dan SQ terhadap Hubungan Antara Partisipasi Anggaran dan Kesenjangan Anggaran. Tesis. Program Pascasarjana Universitas Brawijaya, Malàng.

Ebel, R.L. \& D.A. Frisbie. 1991. Essential of Educational Measurement. Prentice-Hall, Englewood Cliffs.

Fudyartanta, K. 2004. Tes Bakat dan Perskalaan Kecerdasan. Pustaka Pelajar, Yogyakarta.

Goleman, D. 2003. EQ. Cetakan Ketigabelas. PT Gramedia Pustaka Utama, Jakarta. Diterjemahkan oleh T. Hermaya dari Emotional Intelligence, 1995.

Goleman, D. 2005. Kecerdasan Emosi untuk Mencapai Puncak Prestasi. Cetakan Keenam. PT Gramedia Pustaka Utama, Jakarta. Diterjemahkan oleh Alex Tri Kuntjahyo Widodo dari Working with Emotional Intelligence, 1999.

Gujarati, D. 2004. Ekonometrika Dasar. Cetakan Keduabelas. Erlangga, Jakarta. Diterjemahkan oleh Sumarno Zain dari Basic Econometrics, 1978.

Harahap, S.S. 2002. Akuntan Publik di Indonesia dan Kasus Enron. Media Akuntansi 25 (April): 16.

Iyus Yosep, 2005, Pentingnya ESQ (Emosional \& Spiritual Quotion) bagi perawat dalam manajemen konflik, UNPAD

Jusup, A.H. 2001. Auditing (Pengauditan). Bagian Penerbitan Sekolah Tinggi Ilmu Ekonomi YKPN, Yogyakarta.

Khomsiyah \& N. Indriantoro. 1998. Pengaruh Orientasi Etika terhadap Komitmen dan Sensitivitas Etika Auditor Pemerintah di DKI Jakarta. Jurnal Riset Akuntansi Indonesia 1 (1): 1328.

Loeb, S.E. 1971. A Survey of Ethical Behavior in the Accounting Profession. Journal of Accounting Research Autumn: 287-306.

Lovell, A. 2002. Ethics as a Dependent Variable in Individual and Organizational Decision Making. Journal of Business Ethics 37: 145-163.

Ludigdo, U. 1999a. Muatan Etika dalam Kurikulum Pendidikan Tinggi Akuntansi. Makalah pada Seminar yang diselenggarakan Mahasiswa Jurusan Akuntansi UPN "Veteran" Surabaya. Surabaya, 16 September.

Ludigdo, U. 1999b. Pengaruh Gender terhadap Etika Bisnis: Studi atas Persepsi Akuntan dan Mahasiswa Akuntansi. Proceeding Simposium Nasional Akuntansi II. Malang, 24-25 Sepetember : $1-17$.

Ludigdo, U. 2004. Mengembangkan Pendidikan Akuntansi Berbasis IESQ untuk Meningkatkan Perilaku Etis Akuntan. Jurnal TEMA 5 (2): 134-147.

Ludigdo, U. 2005. Pemahaman Strukturasi Atas Praktik Etika di Sebuah Kantor Akuntan Publik. Ringkasan Disertasi. Program Pascasarjana Universitas Brawijaya, Malang.

Magnis-Suseno, F. 2005. Etika Dasar Masalah Pokok Filsafat Moral. Cetakan Ketujuhbelas. Kanisius, Yogyakarta.

Mahmudi. 2001. Manajemen Laba (Earnings Management): Sebuah Tinjauan Etika Akuntansi. Jurnal Bisnis dan Akuntansi 3 (2): 395-403.

Maryani, T. \& U. Ludigdo. 2001. Survei atas Faktor-faktor yang Mempengaruhi Sikap dan Perilaku Etis Akuntan. Jurnal TEMA 2 (1): 49-62.

Pasiak, T. 2002. Revolusi IQ/EQ/SQ : Antara Neurosains dan Al-Quran. Cetakan Pertama. Mizan, Bandung.

Rahmawati, Nur Indah. 2003. Pengaruh Perbedaan Gender terhadap Perilaku Etis Mahasiswa Akuntansi. Skripsi tidak dipublikasikan. Fakultas Ekonomi,Universitas Sebelas Maret, Surakarta. 
Reiss, M.C. \& K. Mitra. 1998. The Effects of Individual Difference Factors on the Acceptability of Ethical and Unethical Workplace Behaviors. Journal of Business Ethics 17: 15811593.

Ruegger, D. \& E.W. King. 1992. A Study of the Effect of Age and Gender upon Student Business Ethics. Journal of Business Ethics 11: 179-186.

Santoso, K. 2002. Dampak Kebangkrutan Enron terhadap Citra Profesi Akuntan Publik. Media Akuntansi 25 (April): 17-19.

Santoso, S. 2003. Buku Latihan SPSS Statistik Non Parametrik. PT Elex Media Komputindo, Jakarta.

Sekaran, U. 2003. Research Methods for Business: A Skill Building Approach. Fourth Edition.

"John Wiley \& Sons, Inc., New York.

Sugiyono. 2002. Metode Penelitian Administrasi. Cetakan Kedelapan. Alfabeta, Bandung.

Sihwajoni, dan M. Gudono, 2000, "Persepsi akuntan terhadap kode etik akuntan", Jurnal Riset Akuntansi Indonesia, Vol 3 (2) Juli: 168184.

Suryabrata, S. 2000. Pengukuran dalam Psikologi Kepribadian. Pidato Pengukuhan Guru Besar Ilmu-Ilmu Sosial Unversitas Gadjah Mada Yogyakarta. Gadjah Mada University Press, Yogyakarta.

Suryaningsum, S; S. Heriningsih \& A. Afuwah. 2004. Pengaruh Pendidikan Tinggi terhadap EQ. Proceeding Simposium Nasional Akuntansi VII. Denpasar, 2-3 Desember: 351-369.

Svyantek, D.J. 2003. Emotional Intelligence and Organizational Behavior. The International Journal of Organizational Analysis 11 (3): 167-169.

Trisniwati, E.I. \& S. Suryaningsum. 2003. Pengaruh EQ terhadap Tingkat Pemahaman Akuntansi. Proceeding Simposium Nasional Akuntansi VI. Surabaya, 16-17 Oktober: 1073-1091.

Triyuwono, I. 2002. Strategi Pendidikan Etika Bisnis dan Profesi pada Pendidikan Akuntansi. Jurnal TEMA 3 (2): 118-132.

Tyson, T. 1992. Does Believing that Everyone Else is Less Ethical have an Impact on Work Behavior?. Journal of Business Ethics 11: 707-717.

Umar, H. 2002. Metode Riset Bisnis. Cetakan Pertama. PT Gramedia Pustaka Utama, Jakarta.

Ummah, k., D. Mahayana \& A. Nggermanto. 2003. SEPIA: Kecerdasan Milyuner, Warisan yang Mencerahkan Keturunan Anda. Cetakan Pertama. Ahaa, Bandung.

Verbeke, W; C. Ouwerkerk \& E. Peelen. 1996. Exploring the Contextual and Individual Factors on Ethical Decision Making of Salespeople. Journal of Business Ethics 15: 1175-1187.

Ward, S.P., D.R. Ward \& A.B. Deck. 1993. Certified Public Accountants: Ethical Perception Skills and Attitudes on Ethics Education. Journal of Businwess Ethics 12: 601-610.

Weaver, G.R. \& B.R. Agle. 2002. Religiosity and Ethical Behavior in Organizations: A Symbolic Interactionist Perpective. Academy of Management Review 27 (1): 77-97.

Wimbush, J.C.; J.M. Shepard \& S.E. Markham. 1997. An Empirical Examination of the Relationship between Ethical Climate and Ethical Behavior from Multiple Levels of Analysis. Journal of Business Ethics 16: 1705-1716.

Zohar, D. \& I. Marshall. 2002. SQ : Memanfaatkan SQ dalam Berpikir Holistik untuk Memaknai Kehidupan. Cetakan Kelima. Mizan, Bandung. Diterjemahkan oleh Rahmani Astuti, Ahmad Nadjib Burhani \& Ahmad Baiquni dari SQ: Spiritual Intelligence-The Ultimate Intelligence, 2000 